\title{
Parents' knowledge about the oral health care of oncological children
}

\author{
Conhecimento dos pais de crianças \\ oncológicas em saúde bucal
}

\author{
Bruna Rafaele Vieira PEDROSA 1 iD 0000-0003-4246-4885 \\ Walésia Laianny Leite MARTINS ${ }^{1}$ iD 0000-0003-4928-8845 \\ Híttalo Carlos Rodrigues de ALMEIDA ${ }^{1}$ iD 0000-0003-4928-8845 \\ Veronica Maria da Rocha KOZMHINSKY ${ }^{1}$ (D) 0000-0002-4903-4899 \\ Maria de Fátima Pessoa de Araújo SABINO ${ }^{1}$ iD 0000-0001-7232-1231 \\ Kaline Maria Maciel de OLIVEIRA ${ }^{1}$ iD 0000-0003-0892-6847
}

\section{ABSTRACT}

Objective: identifying the parents/guardians' knowledge about the oral health condition of oncological children assisted at the Pediatric Oncology Department of the Institute of Integral Medicine Professor Fernando Figueira. Methods: A cross-sectional study comprising a sample of 163 parents/guardians of children assisted at the Pediatric Oncology Department of the IIMP in the city of Recife, Pernambuco, applying a semi-structured form, tested with $10 \%$ of the sample in a pilot study. Results: Most of the parents/ guardians were female subjects (87\%) and patients' mothers (81\%), between 25 and 34 years of age (44.8\%), with a family income of a minimum wage (47\%), educational level until elementary school (51.6\%) and from the countryside of the state of Pernambuco (56\%). Most of the children were male subjects (58.9\%) with average age of 7.57 years, who had attended or stopped primary school (54.6\%) and had been diagnosed with Acute Lymphoblastic Leukemia (57.7\%) and treated with chemotherapy (92.6\%). All parents considered important to have dental surgeons in the oncology department assisting the children in their oral hygiene. More than half of these parents reported knowing about how to avoid caries (63\%) and, almost half of the children had never had a consultation with a dentist before (41.1\%). Conclusion: Parents/guardians have information about oral health care, but they do not put it into practice.

Indexing terms: Child health. Health care. Oral health.

\section{RESUMO}

Objetivo: Identificar o conhecimento dos pais/responsáveis de crianças oncológicas sobre os cuidados de saúde bucal dedicados aos seus filhos acompanhados na oncologia pediátrica do Instituto de Medicina Integral Prof. Fernando Figueira. Métodos: Estudo transversal, com amostra de 163 Pais/responsáveis de crianças acompanhadas pelo Setor de Oncologia Pediátrica do IMIP na cidade do Recife/PE através da aplicação de formulário semiestruturado, testado com 10\% da amostra em um estudo-piloto. Resultados: Os

$\boldsymbol{\nabla} \nabla \nabla v$

1 Instituto de Medicina Integral Prof. Fernando Figueira, Residência em Odontopediatria. Rua dos Coelhos, 300, Boa Vista, 50070-902, Recife, PE, Brasil. Correspondência para / Correspondence to: BRV PEDROSA. E-mail: <brunarvpedrosa@gmail.com>.

$\boldsymbol{\nabla} \boldsymbol{\nabla} \boldsymbol{v}$

How to cite this article

Pedrosa BRV, Martins WLL, Almeida HCR, Kozmhinsky VMR, Sabino MFPA, Oliveira KMM. Parents' knowledge about the oral health care of oncological children. RGO, Rev Gaúch Odontol. 2019;67:e2019008. http://dx.doi.org/10.1590/1981-86372019000083605 
pais/responsáveis em sua maioria pertenciam ao sexo feminino (87\%), eram mães dos pacientes (81\%), com idade entre 25 a 34 anos (44,8\%), com renda familiar de um salário mínimo (47\%), com escolaridade até o ensino fundamental (51,6\%) e do interior do Estado de Pernambuco (56\%). As crianças na maior parte eram do sexo masculino (58,9\%) e tinha idade média de 7, 57 anos, cursavam ou haviam parado de estudar no ensino fundamental (54,6\%), foram diagnosticados com Leucemia Linfóide Aguda (57,7\%) e tratados através de quimioterapia (92,6\%). Todos os pais consideravam importante a presença do cirurgião dentista no Setor de Oncologia e realizavam a higiene bucal da criança, mais da metade afirmaram ter conhecimento sobre como evitar a cárie (63\%) e quase metade das crianças nunca foram ao dentista $(41,1 \%)$. Conclusão: Os pais/responsáveis possuem conhecimento sobre saúde bucal, mas não colocam em prática.

Termos de indexação: Saúde da criança. Assistência à saúde. Saúde bucal.

\section{INTRODUCTION}

Over time, dentistry has made great progress about technical and scientific knowledge and preventive actions. However, even with such progress, oral diseases continue reaching a large part of the population, because, although the benefits of a change in lifestyle are widely known by professionals and widespread in the media, they are not always known by the overall population [1,2].

Considering children, cancer can be understood as a group of non-contagious diseases that affect children and adolescents from 0 to 19 years of age. In Brazil, the incidence of all types of cancer in children and adolescents under 18 years of age ranges from $1.5 \%$ to $6.5 \%$, with a risk of 20 to 250 new cases per year/million, being the first cause of death due to illness (7\% of the total) among children and adolescents (1 - 19-year-old subjects) in Brazil. For the biennium 2016/2017, the National Cancer Institute ( $\mathrm{NCl}$ ) estimated a total of 12,600 new cases, being the majority of the cases registered in the Southeast (6050) and Northeast (2750) regions [3]. The neoplasms with the highest incidence are leukemias, central nervous system tumors, lymphomas, bone tumors, muscle and kidney tumors, in which the primary forms of treatment are chemotherapy, radiotherapy and surgery $[4,5]$ Leukemia accounts for $50 \%$ of children who die from cancer, being the mouth commonly compromised. Stomatologic manifestations may occur in the early stage of the disease, increasing when antileukemic therapy is applied due to immunosuppression [6]. Most of the time, chemotherapy is the treatment of choice for this neoplasm. Chemotherapeutic drugs act primarily in the tumor cells, destroying them or preventing their reproduction, without distinguishing malignant cells from regular cells of the oral mucosa [7].

If the patient presents odontogenic and/or periodontal infections prior to undergoing chemotherapy and/or radiotherapy and, such patient does not have good oral hygiene, the risk of developing oral infections is increased and hematogenous dissemination may occur, compromising other organs during the periods of myelosuppression that is induced by chemotherapy. Therefore, it is necessary to be aware that many children, even before starting treatment, may present several oral health problems that may lead to the interruption of the cancer treatment [5].

The prevention of oral diseases in children and adolescents under oncological treatment is very important, since oral lesions, resulting from this therapy, considerably worsen the clinical condition and the risk of infection and, also, make it difficult to perform dental work when necessary $[6,8]$.

Dentistry, applied to pediatric oncology patients, plays a key role in keeping the overall health condition and, consequently, the quality of life of these children [9]. Poor oral health conditions are key etiologic factors to stomatologic and systemic complications, which can lead to patient's death [10].

Thus, the objective of the present research study was to identify the knowledge that parents/guardians have about the oral health of oncological children. Such children were assisted at the Pediatric Oncology Department of the Institute of Integral Medicine Professor Fernando Figueira (IIMP), in Recife city, state of Pernambuco.

\section{METHODS}

A cross-sectional study was carried out from May to September 2016, comprising a sample of 163 parents/ guardians of children assisted at the Pediatric Oncology Department of the Institute of Integral Medicine Professor Fernando Figueira (IIMP), in Recife/PE. The following subjects were excluded from the study: Parents/guardians from patients who did not have a diagnosis set by the oncology department; patients unaccompanied by their 
parents/guardians at the time of the research study; parents/guardians presenting cognitive impairment, making it impossible to fulfill the form.

The study was carried out applying a form developed according to the variables of the study and was addressed to parents/guardians, being tested with $10 \%$ of the sample in a pilot study. The form was applied during the follow-up visit to patients hospitalized in the wards area or in the standby time of the consultation at the outpatient clinic of the Pediatric Oncology Department of the institution.

Data were analyzed descriptively by absolute and percentage frequencies for categorical variables and measures: average age of the parents/guardians and the patients. To evaluate the association between two categorical variables, the Pearson's Chi-square test or Fisher's exact test were applied when the conditions for use of the Chi-square test were not verified. The margin of error for the statistical test was $5 \%$. The project was approved by the Research Ethics Committee of the institution in accordance with the Resolution 466/2012 under protocol 1.967.956.

\section{RESULTS}

163 parents/guardians participated into this research study, of which $87 \%$ were female subjects, $44.8 \%$ were in the age group of $25-34$ years of age, $51.6 \%$ had finalized elementary school, $47 \%$ had family income of a minimum wage, $56 \%$ were from the country side of the state of Pernambuco and $81 \%$ of the interviewed were patient's mothers. Regarding the patients, 58.9\% were male subjects with average age of 7.57 years, $54.6 \%$ had attended elementary school, $57.7 \%$ had been diagnosed with acute lymphoblastic leukemia (ALL) and 92.6\% \% had been treated applying chemotherapy. Regarding the oral health behavioral factors, it was verified that 51.5\% of the parents considered their own oral health as regular and $67.5 \%$ of parents classified the oral health of their child as good/excellent. This study verified that $62 \%$ of the interviewed had information about how to prevent caries, $46.6 \%$ had already received oral health advice by the dental surgeons from the department, assessing it very positively. Following-up, $33.7 \%$ of the interviewed had attended some oral hygiene educational program, and all the children performed oral hygiene, in which $54.6 \%$ of the oral hygiene was carried out by the parents/guardians and $45.4 \%$ were performed by the children themselves, $60.1 \%$ used to brush their teeth three times a day, 97,5\% used toothbrushes and $96.5 \%$ toothpaste.

As for visit to the dentist, $41.1 \%$ of the children had never been to the dentist, $31.9 \%$ had been to the dentist for less than 6 months, $12.9 \%$ had been for less than a year and $14.1 \%$ had been for more than a year. Among those who had had a consultation with the dentist, $25.2 \%$ of the visits had been at the IIMP and for $42.9 \%$ the reason for the visit was treatment/urgency, in which only $16 \%$ of the consultations were for preventive treatment.

When asked if oral health could interfere with the treatment of the child, $74.8 \%$ believed so. All interviewed considered important to have dental surgeons being part of the multidisciplinary team, $80.4 \%$ believe that eating habits interfere with the oral health of the child, 55.8\% stated that the children did not have habits harmful to oral health, and, considering patients who had some habit, $33.7 \%$ of parents considered it harmful to the child's health.

Table 1 shows the association between the sociodemographic variables and the parents/guardians' knowledge, with a statistically significant correlation with the age group and the variables "participation in educational activity related to oral health" ( $p=0.035)$, "Who performs oral hygiene $(p=0.001)$, "Last visit of the child to the dentist" ( $p=0.001)$, "Where was the dental treatment carried out" ( $p=0.013)$ and "reason for the consultation" ( $p=0.002)$.

Table 2 shows statistically significant associations between the sociodemographic variable education and parents/guardians knowledge regarding the "reason for the consultation" ( $p=0.001)$, "information about how to avoid caries" ( $p=0.001$ ) and "eating habits interference in the oral health of the child" ( $p=0.034)$.

Table 3 shows a statistically significant association between the educational level and the variables "classification of the oral health of parents/guardian" ( $p=$ 0.003 ) and "classification by the parents of the oral health condition of their children" ( $p=0.013)$. 
Table 1. Association of parents/guardians' knowledge according to their age group. IMIP (2017).

\begin{tabular}{|c|c|c|c|c|c|c|c|c|c|}
\hline \multirow{3}{*}{ Variable } & \multicolumn{6}{|c|}{ Bracket age } & & & \multirow{3}{*}{ P value } \\
\hline & \multicolumn{2}{|c|}{18 to 24} & \multicolumn{2}{|c|}{25 to 34} & \multicolumn{2}{|c|}{35 or over } & \multicolumn{2}{|c|}{ Total Group } & \\
\hline & $\mathrm{n}$ & $\%$ & n & $\%$ & $\mathrm{n}$ & $\%$ & $\mathrm{n}$ & $\%$ & \\
\hline Total & 26 & 100 & 73 & 100 & 64 & 100 & 163 & 100 & \\
\hline \multicolumn{10}{|c|}{ Have you ever participated in any educational activity related to oral health? } \\
\hline Yes & 5 & 19.2 & 32 & 43.8 & 18 & 28.1 & 55 & 33.7 & $\mathrm{p}^{(1)}=0.035^{*}$ \\
\hline No & 21 & 80.8 & 41 & 56.2 & 46 & 71.9 & 108 & 66.3 & \\
\hline \multicolumn{10}{|c|}{ How often does the child perform oral hygiene? } \\
\hline Once & 1 & 3.8 & 6 & 8.2 & 2 & 3.1 & 9 & 5.5 & \\
\hline Twice & 6 & 23.1 & 12 & 16.4 & 13 & 20.3 & 31 & 19 & $\mathrm{p}^{(1)}=0.731$ \\
\hline Three times & 16 & 61.5 & 41 & 56.2 & 41 & 64.1 & 98 & 60.1 & \\
\hline Four times or more & 3 & 11.5 & 14 & 19.2 & 8 & 12.5 & 25 & 15.3 & \\
\hline \multicolumn{10}{|c|}{ Who performs the oral hygiene of the child? } \\
\hline Child & 5 & 19.2 & 27 & 37 & 42 & 65.6 & 74 & 45.4 & $\mathrm{p}^{(2)}<0.001^{*}$ \\
\hline Other (Parents/Guardians/Nurse) & 21 & 80.8 & 46 & 63 & 22 & 34.4 & 89 & 54.6 & \\
\hline \multicolumn{10}{|c|}{ When did the child go to the dentist for the last time? } \\
\hline The child has never been to the dentist & 19 & 73.1 & 31 & 42.5 & 17 & 26.6 & 67 & 41.1 & \\
\hline Less than 6 months & 3 & 11.5 & 23 & 31.5 & 26 & 40.6 & 52 & 31.9 & $\mathrm{p}^{(2)}=0.001^{*}$ \\
\hline Less than 1 year & 1 & 3.8 & 13 & 17.8 & 7 & 10.9 & 21 & 12.9 & \\
\hline 1 year or more & 3 & 11.5 & 6 & 8.2 & 14 & 21.9 & 23 & 14.1 & \\
\hline \multicolumn{10}{|c|}{ Where was the dental treatment performed? } \\
\hline The child has never been to the dentist. & 19 & 73.1 & 31 & 42.5 & 17 & 26.6 & 67 & 41.1 & \\
\hline IIMP & 3 & 11.5 & 19 & 26 & 19 & 29.7 & 41 & 25.2 & \\
\hline Private & 3 & 11.5 & 7 & 9.6 & 14 & 21.9 & 24 & 14.7 & \\
\hline Public & 1 & 3.8 & 10 & 13.7 & 9 & 14.1 & 20 & 12.3 & \\
\hline Other & - & - & 6 & 8.2 & 5 & 7.8 & 11 & 6.7 & \\
\hline \multicolumn{10}{|l|}{ What is the reason for the consultation? } \\
\hline The child has never been to the dentist. & 19 & 73.1 & 31 & 42.5 & 17 & 26.6 & 67 & 41.1 & \multirow{3}{*}{$\mathrm{p}^{(2)}=0.002^{*}$} \\
\hline Prevention & 1 & 3.8 & 11 & 15.1 & 14 & 21.9 & 26 & 16 & \\
\hline Treatment/Urgency & 6 & 23.1 & 31 & 42.5 & 33 & 51.6 & 70 & 42.9 & \\
\hline
\end{tabular}

Note: $\left(^{*}\right)$ Significant difference at the level of 5.0\%. (1) Through Fisher's exact test. (2) Through Pearson's Chi-square test.

\section{DISCUSSION}

According to the results found in this research study, most interviewed were children's mother, as in the study by Barbosa et al. [8]. The age, low educational level, family income of a minimum wage and the source found in our study are in agreement with Rocha et al. [10]. As in this research, additional studies have demonstrated a higher incidence of cancer in male children, such as those by Lopes et al. [7], Barbosa et al. [8] and Santos et al. [6]. Slightly more than half of the patients were diagnosed with ALL, and most of them underwent chemotherapy as treatment. The same result was observed in the studies by Lopes et al. [7], Santos et al. [6] and Figueiredo \& Nogueira [11]. Oral health is critical for health, since it is through the mouth that individual feeds, thus obtaining the nutrients necessary to be alive and healthy, as well as other functions. When some factors such as lack of oral hygiene, frequent 
Table 2. Parents/guardians' knowledge according to their educational level. IMIP (2017).

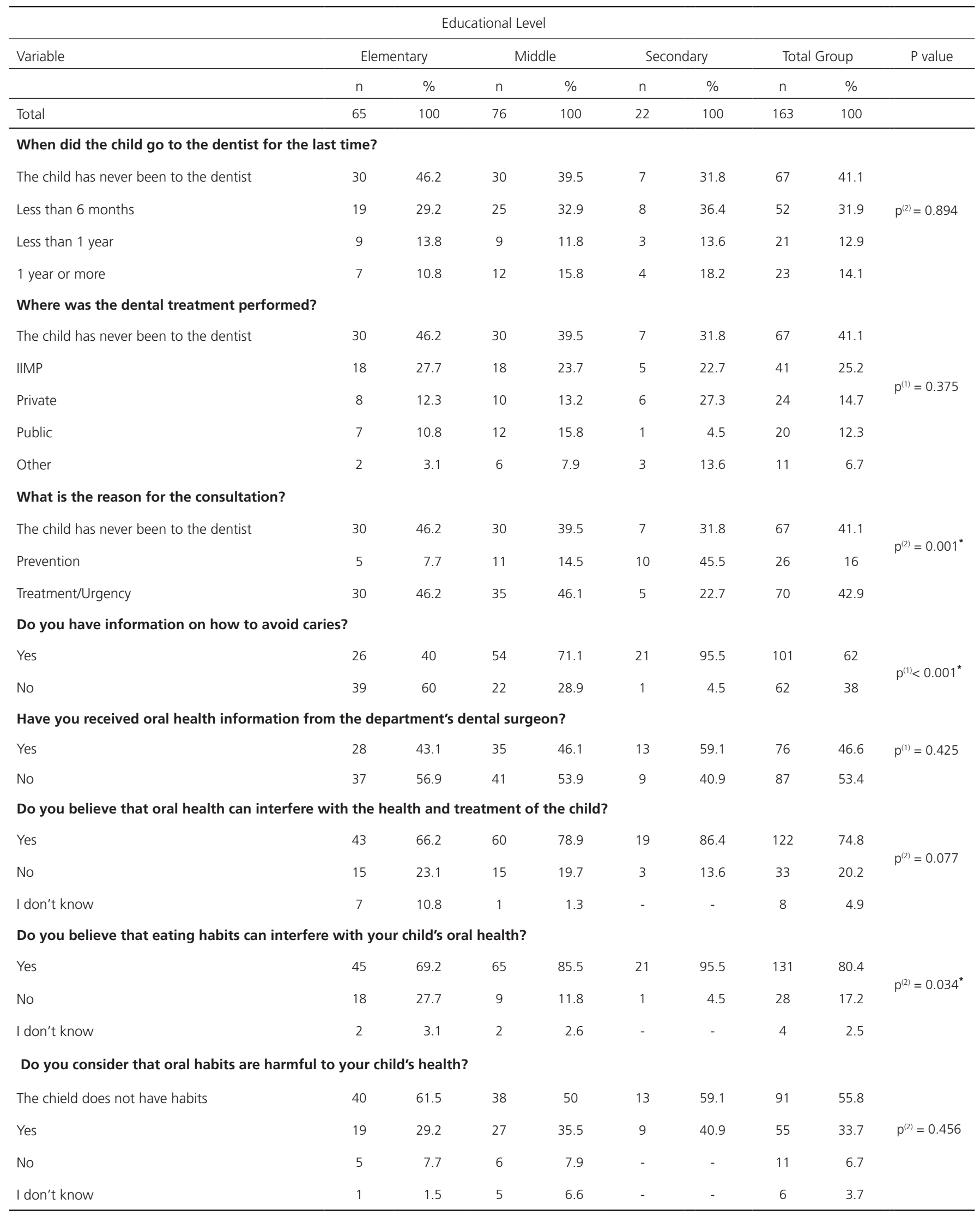

Note: $\left(^{*}\right)$ Significant difference at the level of 5.0\%. (1) Through Pearson's Chi-square test. (2) Through Fisher's exact test. 
Table 3. Association of oral health classification according to the parents/guardians' educational level. IMIP, 2017.

\begin{tabular}{|c|c|c|c|c|c|c|c|c|c|}
\hline \multirow{2}{*}{ Variable } & \multicolumn{6}{|c|}{ Educational Level } & & & \\
\hline & $\mathrm{n}$ & $\%$ & $\mathrm{n}$ & $\%$ & $\mathrm{n}$ & $\%$ & $\mathrm{n}$ & $\%$ & $P$ value \\
\hline Total & 65 & 100 & 76 & 100 & 22 & 100 & 163 & 100 & \\
\hline \multicolumn{10}{|c|}{ How do you rate your oral health? } \\
\hline Good/Excellent & 35 & 53.8 & 17 & 22.4 & 9 & 40.9 & 61 & 37.4 & \\
\hline \multicolumn{10}{|c|}{ How do you rate the child's oral health? } \\
\hline Poor/Bad & 3 & 4.6 & 2 & 2.6 & - & - & 5 & 3.1 & \multirow{2}{*}{$\mathrm{p}^{(2)}=0.013^{*}$} \\
\hline Regular & 15 & 23.1 & 31 & 40.8 & 2 & 9.1 & 48 & 29.4 & \\
\hline
\end{tabular}

Note: $\left(^{*}\right)$ Significant difference at the level of 5.0\%. (1) Through Pearson's Chi-square test. (2) Through Fisher's exact test.

consumption of sugar, harmful habits or oral diseases lead to imbalance of the oral health, it becomes more difficult for a patient to recover [12]

In oral health care, the prevention of caries and periodontal diseases, which are the two major public health problems in dentistry, is established by the effective mechanical control of the dental biofilm through the use of conventional brush, dental floss and diet control [13]. This method, along with professional care, is recognized as the simplest and most effective method to maintain oral health [2]. In the study by Aragão et al. [1], all interviewed showed some knowledge about prevention of oral diseases. In this study, most of the parents also stated that they knew how to avoid dental caries, having received oral health information from the dental surgeon from the department or through participation in educational activities related to oral health. The main care provided by parents is regular brushing, two to three times a day, with toothbrush and toothpaste, which is according to the study by Barbosa et al. [8]. It was also verified that older parents/guardians participated more in educational activities. In this study, children with older parents performed their own brushing, while children with younger parents had their own parents responsible for the brushing as they did not have good motor coordination to perform brushing alone effectively [9].

Among the main forms of prevention are regular visits to the dentist. However, in the aforementioned study, it was found that most of the children had never been to the dentist and that, the younger their parents/guardians, the greater the number of children who had never been to the dentist. Children who had gone to the dentist less than 6 months had older parents/guardians aging over 35 years of age and most of the visits had been at the hospital. Regarding the reason for consultation, it was observed that the older age group and the lower level of education were determinant for the treatment/urgency, also seeing in the studies by Nunes \& Perosa [14] and Gaeta et al. [15]. This is one of the factors that contributes to the demand, or not, of treatment in these children [16].

All the interviewed reported the importance of having a dental surgeon in the hospital setting as part of the oncology team, as reported by Figueiredo \& Nogueira [11] and Machado et al. [17]. It is necessary that dental surgeons provide information to patients and their guardian on the need and importance of oral health care, aiming at improving the health and the quality of life of the patient $[5,7,17]$.

In this study, the classification of the oral health condition of parents/guardians was regular. The lower the educational level, the higher the percentage of parents/ guardians who rated their oral health as good/excellent. Regarding the oral health of the child, the majority rated it as good/excellent, as in the study by Gaeta et al. [15]. The lack of knowledge about the necessary care for oral hygiene is a concern, especially in this group of children in which maintaining the oral hygiene is a key factor for health improvement $[1,5]$. Since the information available in the major media does not reach all the layers of the 
population uniformly, it is difficult to understand it in order to generate knowledge and autonomy in relation to health care [3].

Most parents/guardians believe that oral health can interfere with the treatment of the child. It is known that the ideal for the cancer patient would be to perform all dental treatment before starting anti-neoplastic therapy, since during this treatment some side effects may occur in the oral cavity such as mucositis, xerostomia, dryness, herpes virus infections and/or candida albicans $[14,18]$. Dentistry acts aiming at maintaining the balance of the oral health condition, whether educating parents/guardians and patients in an attempt to establish good oral hygiene habits, or by the treatment of pain and removal of possible sources of infection, avowing odontogenic infection [2].

Generally, when the patients arrive at the Pediatric Oncology Outpatient Clinic of the IIMP, the disease is in an advanced state, mainly because many symptoms can be mistaken by common childhood diseases, thus delaying the diagnosis. When the patient comes from the countryside, as in the aforementioned study, it is even more complicated by the difficulty to access health care services. Late diagnosis makes it necessary to start anti-neoplastic treatment as soon as possible. In addition, many of these children come to treatment showing their oral health very compromised and many of them had never gone to the dentist, making the dental team to act more intensely to minimize the effects caused by treatment.

\section{CONCLUSION}

Knowing the oral health condition and the factors that may influence it are essential to promote behavioral changes that lead to positive attitude towards care, especially in at-risk groups such as cancer patients. In this research study, it was verified that the patients' parents/ guardians have such knowledge, but they do not put it into practice. Therefore, it is necessary to spread the awareness of the benefits of having a good oral health, so that this knowledge becomes a positive attitude, minimizing the suffering of these children. Further clarification is required from dental surgeons about care related to these patients, mainly to increase the access to dental treatment.

\section{Collaborators}

BRV PEDROSA, WLL MARTINS and HCR ALMEIDA participated in the elaboration and development of the research, as well as in data collection and literature review. MFPA SABINO performed the analysis of the results, VMR KOZMHINSKY, wrote the article and literature review and KMM OLIVEIRA, contributed in the data collection and literature review.

\section{REFERENCES}

1. Aragão AKR, Sousa PGB, Ferreira JMS, Duarte RC, Menezes VA de. Conhecimento de professores das creches municipais de João Pessoa sobre saúde bucal infantil. Pesq Bras Odontoped Clin Integr. 2010;10(3):393-398.

2. Antonio LP, Gouvêa GR, Souza LZ, Cortellazzi KL. Avaliação de diferentes métodos educativos em saúde bucal em crianças na faixa etária de 7 a 10 anos de idade. RFO. 2015;20(1) 5258. http://dx.doi.org/10.5335/rfo.v20i1.4525

3. Instituto Nacional do Câncer (INCA). Coordenação de Prevenção e Vigilância do Câncer. Estimativa 2016: incidência de câncer no Brasil. Rio de Janeiro, 2016 [citado 2018 Jan 4]. Disponível em: <http://www.inca.gov.br/estimativa/2016/ sintese-de-resultados-comentarios.asp >.

4. Instituto Nacional do Câncer (INCA). Câncer infantil [citado 2018 Jan 4]. Disponível em: <http://www2.inca.gov.br/wps/ wcm/connect/tiposdecancer/site/home/infantil>.

5. Ribeiro ILA, Valença AMG, Bonan PRF. Odontologia na oncologia pediátrica. João Pessoa: Ideia; 2016.

6. Santos VI, Anbinder AL, Cavalcante ASR. Leucemia no paciente pediátrico: atuação odontológica. Cienc Odontol Bras. 2003;6(2):49-57. http://dx.doi.org/10.14295/bds.2003. v6i2.325

7. Lopes IA, Nogueira DN, Lopes IA. Oral manifestations of chemotherapy in children from a cancer treatment center. Pesq Bras Odontoped Clin Integr. 2012;12(1):113-19. . http:// dx.doi.org/10.5935 /1808-8694.20140015

8. Barbosa AM, Ribeiro DM, Caldo-Teixeira AS. Conhecimentos e práticas em saúde bucal com crianças hospitalizadas com câncer. Ciênc Saúde Coletiva. 2010;15(1):1113-1122. http:// dx.doi.org/10.1590/S1413-81232010000700019

9. Sasada INV, Cancino CMH, Petersen RC, Hellwig I, Dillenburg CS. Prevenção de intercorrências estomatológicas em oncologia pediátrica. RFO. 2015;20(1):105-109. http://dx.doi. org/10. 5335/rfo.v20i1.4861

10. Rocha RS, Pinheiro LP, Oriá MOB, Ximenes LB, Pinheiro AKB, Aquino OS. Determinantes sociais da saúde e qualidade de vida de cuidadores de crianças com câncer. Rev Gaúcha Enferm. 2016;37(3):e57954. http://dx.doi.org/10.1590/19831447.2016.03.57954

11. Figueiredo PBA, Nogueira AJS. Prevalência de Neoplasias, cárie e gengivite em pacientes oncológicos pediátricos. Pesq Bras Odontoped Clin Integr. 2013;13(2):141-46. http://dx.doi. org/10.4034/PBOCI.2013.132.01

12. Costa LRRSM, Zardetto C, Araujo AMPG, Pavez CE, Torres $G R$, Valenzuela IAV, et al. Presença do odontopediatra em ambiente hospitalar. Rev Odontopediatr Latinoam. 2014;4(2). 
13. Veiga N, Carvalho P, Coelho I, Ribeiro O. Eficácia da promoção da saúde oral no controlo do biofilme bucal. Rev Bras Promoç Saúde. 2014;27(1):117-123. http://dx.doi. org/10.5020/18061230.2014.p117

14. Nunes VH, Perosa GB. Cárie dentária em crianças de 5 anos: fatores sociodemográficos, lócus de controle e atitudes parentais. Ciênc Saúde Coletiva. 2017;22(1):191-200. http://dx.doi. org/10.1590/1413-81232017221.13582015

15. Gaeta ML, Cavazos J, Cabrera MRL. Habilidades autorregulatorias, e higiene bucal infantil conelapoyo de los padres. Rev Latinoamericana Cienc Sociales. 2017;15(2):965-978. http:// dx.doi.org/10.11600/1692715x.1521109022016

16. Tannure PN, Rey AC, Silva TT da, Costa M de C, Granjeiro JM, Kuchler EC. A adesão a medidas preventivas em saúde bucal em crianças e adolescentes portadores de fissura labiopalatina. Odontol Clín-Cient. 2011;10(2):153-155.

17. Machado FC, Moreira MR, Cordeiro MS, Carvalho TA. Manifestações orais e condutas em pacientes oncológicos pediátricos: revisão da literatura. Rev Fac Odontol Lins/Unimep. 2017;27(1):37-44. http://dx.doi.org/10.15600/2238-1236/fol. v27n1p37-44

18. Albuquerque RA, Morais VLL, Sobral APV. Odontologic protocol of attendance the pediatric oncology patients: review of literature. Rev Odontol UNESP. 2007;36(3):275-280.

Received on: 17/4/2018 Final version resubmitted on: 18/6/2018 Approved on: 5/12/2018 